\title{
Recent patents in nucleic acid amplification
}

\begin{tabular}{|c|c|c|c|c|c|}
\hline Patent \# & Subject & Assignee & Inventors & $\begin{array}{c}\text { Priority } \\
\text { application } \\
\text { date }\end{array}$ & $\begin{array}{l}\text { Publication } \\
\text { date }\end{array}$ \\
\hline EP 1113082 & $\begin{array}{l}\text { A composition for detecting single-stranded target } \\
\text { nucleic acids in a sample, comprising oligonucleotide } \\
\text { primers, mononucleotides, nucleic acid polymerases, } \\
\text { polynucleotide probes, and a matrix. The composition } \\
\text { is suitable for fully exploiting the documented utility } \\
\text { of the amplification of specific DNA sequences, and } \\
\text { the method is sufficiently sensitive so that the rounds } \\
\text { of amplification are kept to a minimum. }\end{array}$ & $\begin{array}{l}\text { Enzo Biochem } \\
\text { (New York) }\end{array}$ & $\begin{array}{l}\text { Brakel CL, } \\
\text { Spadoro JP }\end{array}$ & 12/29/1989 & $7 / 4 / 2001$ \\
\hline WO 200146463 & $\begin{array}{l}\text { Internal standards comprising a synthetic nucleic } \\
\text { acid made by nonrecombinant techniques; useful for } \\
\text { performing nucleic acid amplification assays quickly } \\
\text { and inexpensively without sacrificing assay specificity } \\
\text { or sensitivity. }\end{array}$ & $\begin{array}{l}\text { Baxter AG } \\
\text { (Volketswil, } \\
\text { Switzerland) }\end{array}$ & $\begin{array}{l}\text { Rieger M, } \\
\text { Schwarz H, } \\
\text { Turecek P, } \\
\text { Zimmermann K }\end{array}$ & 12/22/1999 & $6 / 28 / 2001$ \\
\hline WO 200146462 & $\begin{array}{l}\text { A method for detecting, differentiating, and } \\
\text { quantifying free target nucleic acids in a sample } \\
\text { by determining the total target nucleic acid content } \\
\text { in the sample before and after digestion and } \\
\text { quantifying free target nucleic acids. Used in } \\
\text { pharmaceutical preparations for the determination } \\
\text { and control of a virus inactivation rate of a virus } \\
\text { inactivation step in using a nucleic acid } \\
\text { amplification method. }\end{array}$ & $\begin{array}{l}\text { Baxter AG } \\
\text { (Volketswil, } \\
\text { Switzerland) }\end{array}$ & $\begin{array}{l}\text { Rieger M, } \\
\text { Schwarz H, } \\
\text { Turecek P, } \\
\text { Voelkel D, } \\
\text { Zimmermann K }\end{array}$ & 12/22/1999 & 6/28/2001 \\
\hline US 6245514 & $\begin{array}{l}\text { A fluorescence energy transfer pair with first and } \\
\text { second probes labeled with fluorescein and Cy5 or } \\
\text { Cy5.5, respectively; useful for detecting a target } \\
\text { analyte and for continuous fluorescence monitoring } \\
\text { of DNA amplification. The information obtained is } \\
\text { useful for product identification, sequence alteration } \\
\text { detection, and quantification. }\end{array}$ & $\begin{array}{l}\text { University of } \\
\text { Utah Research } \\
\text { Foundation } \\
\text { (Salt Lake City, UT) }\end{array}$ & Wittwer CT & $6 / 4 / 1997$ & $6 / 12 / 2001$ \\
\hline JP 2001149097 & $\begin{array}{l}\text { An automatic inspection apparatus comprising a } \\
\text { continuous extractor for samples containing nucleic } \\
\text { acids, an amplifier for specifically amplifying desired } \\
\text { nucleic acid contained in the extracted nucleic acid } \\
\text { component, and a detector for the amplified nucleic } \\
\text { acid; useful in forensic medicine and for diagnosing } \\
\text { hereditary diseases. }\end{array}$ & $\begin{array}{l}\text { Olympus Optical } \\
\text { Co. Ltd. (Tokyo) }\end{array}$ & - & 11/29/1999 & $6 / 5 / 2001$ \\
\hline JP 2001136954 & $\begin{array}{l}\text { A device comprising reaction tube holders for } \\
\text { tubes containing nucleic acid samples, a heater, a } \\
\text { temperature sensor, and a control apparatus; useful } \\
\text { for increasing efficiency in processing nucleic acids, } \\
\text { for example, amplification reactions. }\end{array}$ & $\begin{array}{l}\text { Toshiba KK } \\
\text { (Tokyo) }\end{array}$ & - & 8/31/1999 & $5 / 22 / 2001$ \\
\hline US 6221635 & $\begin{array}{l}\text { A method of detecting the presence of a specific } \\
\text { nucleic acid (e.g., bacterial, viral, or parasitic DNA) } \\
\text { in a sample or cell containing DNA that comprises } \\
\text { performing solid-phase amplification of a DNA } \\
\text { template (SPADT); useful in scanning large } \\
\text { genomic fragments for the presence of genes } \\
\text { or gene families. }\end{array}$ & $\begin{array}{l}\text { Wistar Institute } \\
\text { (Philadelphia, PA) }\end{array}$ & $\begin{array}{l}\text { Mukhopadhyay S, } \\
\text { Rovera G }\end{array}$ & 5/6/1999 & $4 / 24 / 2001$ \\
\hline JP 2001008680 & $\begin{array}{l}\text { Amplification of viral, bacterial, or fungal nucleic } \\
\text { acids by adding a biological sample of a host } \\
\text { infected with a microbe directly to the amplification } \\
\text { solution containing polyamine, sulfated poly- } \\
\text { saccharide, and dithiothreitol. The method is useful } \\
\text { for direct nucleic acid amplification without } \\
\text { preprocessing. }\end{array}$ & $\begin{array}{l}\text { Shimadzu Corp. } \\
\text { (Kyoto, Japan) }\end{array}$ & - & 6/30/1999 & $1 / 16 / 2001$ \\
\hline
\end{tabular}

Source: Derwent Information, Alexandria, VA. The status of each application is slightly different from country to country. For further details, contact Derwent Information, 1725 Duke Street, Suite 250, Alexandria, VA 22314. Tel: 1 (800) DERWENT (info@derwent.com). 